\title{
Evaluation Of Preparedness Program In Disaster Resilient Village Activities In The Regional Disaster Management Agency
}

\author{
Husaini*, Lenie Marlinae*, Laily Khairiyati*, Agung Waskito*, Melan Sari**, Anugrah Nur Rahmat*, Winda \\ Saukina Syarifatul Jannah*, Taufik*, Andre Yusufa Febriandy*, Ammara Ulfa Azizah* \\ *Public Health Study Program, Faculty of Medicine, Lambung Mangkurat University, Indonesia \\ ** Faculty of Medicine, Lambung Mangkurat University, Indonesia
}

DOI: 10.29322/IJSRP.11.07.2021.p11588

http://dx.doi.org/10.29322/IJSRP.11.07.2021.p11588

\begin{abstract}
Disaster is a phenomenon resulting from changes in ecosystems that occur suddenly in a relatively short time in the relationship between humans and their environment that occur in such a way, such as earthquakes, floods, volcanoes that require immediate countermeasures. Disasters that often occur are volcanic eruptions, earthquakes, tsunamis, floods, droughts, hurricanes and forest fires in Indonesia. Based on data collected by the National Disaster Management Agency (BNPB) that the disasters that occurred in Indonesia during 2016 reached 2,384 events which were dominated by disasters such as floods, landslides and tornadoes. Article searches are carried out using a search engine using Google Scholar with the keywords used are human resource input, funding input, infrastructure input, quantity output, quality output, timeliness and target output. Based on the results of the literature review, it was found 12 articles that discussed human resource input, funding input, infrastructure input, quantity output, quality output, timeliness output and targets on preparedness programs in disaster resilient village activities at the Regional Disaster Management Agency (BPBD).
\end{abstract}

Index Terms- Input, Output, Regional Disaster Management Agency

\section{INTRODUCTION}

Observing the geographical, geological, hydrological and demographic conditions, in fact the territory of the Unitary State of the Republic of Indonesia has a high level of vulnerability to disasters, whether caused by natural factors, non-natural factors and human factors. The main impacts of disasters often cause human casualties, environmental damage, property losses, and the impact of non-material and psychological damage. Although development planning in Indonesia has been designed in such a way with the intent and purpose of improving people's welfare, increasing a sense of justice, as well as minimizing the impact of damage that occurs on the environment and protecting the community against the threat of disasters, there are still problems with handling efforts that are not systemic and lack coordination (Razikin et al, 2017).

Disaster is a phenomenon resulting from changes in ecosystems that occur suddenly in a relatively short time in the relationship between humans and their environment that occur in such a way, such as earthquakes, floods, volcanoes that require immediate countermeasures. Disasters that often occur are volcanic eruptions, earthquakes, tsunamis, floods, droughts, hurricanes and forest fires in Indonesia. Based on data collected by the National Disaster Management Agency (BNPB) that the disasters that occurred in Indonesia during 2016 reached 2,384 events which were dominated by disasters such as floods, landslides and tornadoes (Malahika, Rompas and Bawotong, 2016; Razikin et al, 2017).

Indonesia has experienced various disasters in the period 2013-2018. According to data from the National Disaster Management Agency (BNPB), there have been 105 earthquake cases, 3,179 tornado cases, and 40 volcanic eruptions. In addition to natural disasters, Indonesia also experienced cases of non-natural disasters such as 22 cases of fire, 152 cases of transportation accidents, and 10 cases of social unrest. Three Central Java Provinces were ranked first in the regions experiencing the most disasters in Indonesia in the period 2013 - 2018 followed by West Java and East Java (Sasikome, Kumaat and Mulyadi, 2015; Syarif, 2015).

Based on data from the BPBD of South Kalimantan Province in the Field of Preparedness and Prevention, it has provided information or counseling to the district regarding disaster preparedness, provided socialization on CommunityBased Disaster Management (PBBM), provided socialization of disaster management rehearsals and provided training with disaster volunteers. Each sub-district office is also provided with a radio device to report flood events to the community to the BPBD. Efforts and preparedness that can be done to anticipate flood disasters can increase knowledge, attitudes and emergency response in disaster preparedness, including by conducting learning, training, and discussions at the regional, national, and international levels. The learning process can be provided by government institutions, communities working in the field of disaster, schools, mass media, informal learning, and on campus. The plan for disaster emergency response is an important part of preparedness because it relates to evacuation, rescue and rescue so that disaster victims can be minimized and the community can be prepared in the event of a flood disaster in the first days after the disaster and before assistance from the government from outside parties is petrified (Harahap, Lufti and Muthalib, 2015; Erlia, Kumalawati and Aristin, 2017).

\section{IDENTIFY, RESEARCH AND COLLECT DATA}

Article searches are carried out using a search engine using Google Scholar with the keywords used are human 
ISSN 2250-3153

resource input, funding input, infrastructure input, quantity output, quality output, timeliness and target output. The total number of articles obtained was 912. After the articles were excluded because they did not meet the inclusion criteria, 12 articles were found that were suitable for review.

\section{DISCUSSION \\ A. Human Resource Evaluation}

Disaster management is defined as a collective term that covers all aspects of planning for disaster response, including pre-disaster and post-disaster activities which also refers to the management of disaster risks and consequences. Disaster management includes plans, structures, and arrangements made by involving the efforts of the government, volunteers, and the private sector in a coordinated and comprehensive manner to respond to all emergency needs and on that basis, disaster management consists of all planning, organizing and mobilizing resources. human resources needed to handle all phases of disasters as unique natural events (Ferdiansyah, Sugiarti C, Atthahara H, 2020). In addition to requiring adequate physical facilities in policy implementation, every policy must be supported by adequate human resources. In handling flood disasters, quality and sufficient human resources are one of the important factors in implementing flood management so that it can run optimally (Ferdiansyah, Sugiarti C, Atthahara H, 2020).

In the context of developing a Disaster Resilient Village, several efforts were made to increase the capacity of the community and the apparatus in disaster management. The socialization of the Disaster Resilient Village Development Program with the community and community leaders was carried out to provide an overview of the implementation of the Destana program as well as obtain input and suggestions to develop a strategy for implementing the Destana program. In addition, the community was also given Participatory Action Research (PAR) Training to Recognize Local Wisdom for Disaster Risk Reduction (Sulistiyani AT, Yuliani K, Yuliana M, 2017). Basic Training for the Development of the Disaster Resilient Village Program was also provided to the community and village officials to provide knowledge about the development of the Disaster Resilient Village program and the strategies carried out. Training on Basic Concepts of Disaster Management was also given to the community and the Lam Teungoh Village apparatus to provide an understanding to the community about the concept of disaster management, disaster paradigm shifts, and disaster management programs. This training also aims to equalize public perceptions of the concepts and terms used in disaster management (Rina Suryani Oktari, 2019).

In implementing a program, it is very important to have a large number of human resources to support the achievement of a program. However, what happens is that human resources are still lacking so that the program does not run optimally. Usually there are only three active human resources at this time so that it is not optimal in carrying out disaster-resilient village programs. But the strength of the program in the form of human resources for disaster preparedness groups is quite a lot. They are volunteers who are willing to serve to help the community. In addition, this is also supported by the ability of village officials to take care of administrative matters needed to the City BPBD so that the program can be implemented (Salwa R, Alhadi Z, 2019).

The effectiveness of local government performance in disaster management in disaster and disaster management, it is necessary to pay attention to the achievement of organizational goals is the creation of quality human resources, namely by holding advanced education and training, but in practice further education and training do not run properly. The minimum number of employees involved makes the creation of human resource development slow and these activities are not carried out routinely. Education and training are the main factors in developing human resource capabilities. In the context of the process of developing quality human resources owned by the City BPBD, education and training are needed to be able to develop physical abilities and knowledge so that they can realize disaster and disaster management quickly, precisely and safely (Sadat A, 2016).

Organizational performance is a description of the work of the organization in achieving its goals which of course will be influenced by the resources owned by the organization. The resources in question can be physical such as human resources or non-physical such as regulations, information and policies, so to better understand the factors that can affect an organization's performance. The concept of organizational performance also illustrates that every public organization provides services to the community and its performance can be measured using existing performance dimensions to see whether the organization has carried out its duties properly and to find out whether its goals have been achieved or not (Ambo AA, Sulandari S, Widowati N, 2016).

\section{B. Funding Evaluation}

Disaster Resilient Village has allocated special funds to be used for disaster risk reduction which is budgeted from village funds through village meetings. Likewise, funds for emergency response have been budgeted specifically considering that every year it occurs in the event of a disaster, so that the allocation of emergency response funds has been budgeted from village funds. Efforts have also been made to allocate village budgets for DRR activities, such as the construction of buildings for temporary gathering points, procurement of disaster management equipment and disaster management training. The Village Head together with his apparatus has carried out many disaster management efforts, including through disaster training activities for village government officials, training related to the mechanism for maintaining and using equipment, equipment, facilities and infrastructure, and first aid training when a flood occurs. This training is aimed not only at village officials but also to the community and disaster preparedness volunteers in the village. The aim is to seek disaster risk reduction, emergency response operations, and post-disaster recovery (Najib A, Rahmat HK, 2021).

Integrate risk reduction plan into Development and Legalization Plan. In addition to the preparation of the Village Disaster Risk Reduction action plan, this program is also expected to support the integration of Disaster Risk Reduction into the Kecamatan Development Plan. It may be difficult to access funds if it is independent because it will compete with other development programs. Therefore, this program is expected not only to take the form of an Action Plan for Village Disaster Risk Reduction but also to encourage the integration of DRR aspects into the Regional Government RPJM, so that it can also include a Disaster Risk Reduction Approach. The Disaster Risk Reduction action plan and the Village Contingency Plan need to be implemented as a whole by the village community. Therefore, funding and allocation of resources is required. This will be further governed by the established guidelines. Based on 
ISSN 2250-3153

this statement, the operationalization of the DRV policy still needs to be carried out in the form of technical guidelines that can guide the community in real activities (Kristian I, Mulyana Y, 2019).

Meanwhile, according to Sari Z's research, in 2017 the non-implementation of disaster management programs and activities was caused by limited funds and lack of coordination between related agencies. Lack of funds and coordination between relevant agencies resulted in programs and activities that had been previously planned not being implemented and achieving the expected goals. Although there are several programs and activities implemented, these programs and activities are carried out in certain or priority locations. Basically, the realization of the activities carried out by the relevant agencies has the achievement of objectives in accordance with the initial planning, such as emergency recovery of critical infrastructure and facilities functions, namely repairing damaged roads and bridges, searching, rescue and evacuation, fulfilling basic needs for food, clothing, and temporary housing. In addition, there are river normalization activities and the construction of a safety embankment (Sari Z, 2017).

\section{Evaluation of Facilities and Infrastructure}

The Work Environment at BPBD Garut Regency was explained by the Secretary of the Agency and the Head of the Division that the office environment was relatively conducive because he had just occupied the land and had a new office to support work. It's just that for other supporting facilities and infrastructure, including warehouses for storing disaster-related goods, there is no specific place ideally for goods storage/warehouses. First Strategy BPBD prepares a warehouse for facilities and infrastructure and separates consumables from supporting facilities. Based on the results of research and participatory observations, researchers still found that items used to support disaster activities were placed in inappropriate places, such as a generator that had to be installed in a warehouse that was still placed in the office (Kristian I, Mulyana Y). Based on Law Number 24 of 2007 concerning Disaster Management, reconstruction is the rebuilding of all infrastructure and facilities, institutions in post-disaster areas, both at the government and community levels with the main target of growing and developing economic, social and cultural activities, as well as the rise of participation community in all aspects of social life in post-disaster areas (Ferdiansyah, Sugiarti C, Atthahara H, 2020).

According to Edward III in Hasibuan 2016 physical facilities are an important factor in policy implementation. In this case, the City BPBD prepares facilities and infrastructure to support adequate flood disaster management, but the BPBD itself still admits that they still lack disaster support equipment. According to data sourced from the Strategic Plan of the City BPBD for 2018-2023, it shows that in terms of disaster management facilities and infrastructure owned by the City BPBD in general, it is still inadequate. In general, based on the results of interviews with disaster victims, the evacuation of disaster victims cannot be carried out optimally and comprehensively for disaster victims, because the City BPBD Task Force personnel are still not sufficient and in terms of equipment owned by BPBDs are still inadequate because of the large number of facilities and infrastructure. damaged even to the point of heavy damage. This is evidenced by the statements of residents who feel that the evacuation was carried out independently without assistance from BPBD officers (Ferdiansyah, Sugiarti C, Atthahara H, 2020).

Improvements to facilities and infrastructure are also carried out at the post-disaster stage. It can be re-established the conditions of people's lives as before. Increase the atmosphere of mutual cooperation among the community. The more solid public trust in the government and SAR. Rehabilitation of disaster-affected areas can be carried out so that the existing facilities and infrastructure can function again in order to reduce the suffering of the people affected by the disaster. It is possible to rebuild environmental infrastructure and government infrastructure damaged by the disaster. It can prevent misuse and irregularities in the distribution of social assistance. Postdisaster reconstruction, carried out by the Baubau City BPBD through better development activities includes (Sadat A, 2016):

a. Redevelopment of facilities and infrastructure.

b. Redevelopment of community social facilities.

c. Reviving the socio-cultural life of the community.

d. Participation and participation of community organizations, the business world and the community.

Members of the Village Disaster Risk Reduction forum are sufficiently trained because they routinely conduct scheduled disaster management training every year at the Regency level (Regency BPBD) in line with the aims and objectives of BNPB Head Regulation No. 1 of 2012 concerning General Village Guidelines. Disaster Risk Reduction activities at the village level have not been widely implemented because they still refer to activities at the Regency level (District BPBD). Efforts to map and analyze threats, assess vulnerability, and increase community capacity have been carried out as an effort to reduce flood risk. Evacuation routes and temporary evacuation points or gathering points for evacuation sites in the event of a flood already exist and are equipped with emergency facilities such as first aid kits, medicines and emergency lighting. For then flood victims will be evacuated at the command post which is usually at the sub-district office (Najib A, Rahmat HK, 2021).

\section{Evaluation Method}

As an early warning effort to the community, information has been disseminated through meetings, for example at routine social gathering activities in each RT, as well as in the form of leaflets. This effort proved to be effective in the village even though it was carried out in a simple way, because at the time of disseminating the information, an understanding was given of who did what, how to provide assistance to vulnerable groups, as well as how to prepare for the flood by simulating flooding, evacuating victims, and self rescue. Protection for vulnerable groups such as pregnant women, the elderly, people with special needs, and children is carried out using methods and techniques carried out by all village officials including the RT and RW heads together with village health workers such as midwives, assisted by health workers from the sub-district. Efforts to protect village assets are also carried out by village officials. As for livestock, it is done in cooperation with fellow citizens. But it has not been carried out with clear and measurable management and mechanisms (Najib A, Rahmat HK, 2021).

Meanwhile, according to research by Margono et al. in 2019, it showed the realization of the 2016 Magelang Regency Regent's Regulation regarding the stages of implementing disaster management at the pre-disaster stage. With this socialization activity, the community will be able to exercise vigilance and preparedness in anticipating disaster victims. The 
ISSN 2250-3153

Magelang Regency Volcano Alert Status which has been set since May 21, 2018 is an early warning so that the community does good planning in anticipating disasters. While efforts to reduce disaster risk of the community as much as $66 \%$ have carried out activities, namely by introducing disaster-prone maps, disaster mitigation efforts and simulations of disasters. In terms of evacuation, planning for a sister vallage program has been carried out by coordinating with villages in KRB with villages in safe areas in Magelang Regency. This study confirms the research conducted by Kaharjono in which showed that communication management in disaster management in Magelang Regency was good, namely the sister vallage method and the disaster resilient village program (Margono, Amin MK, Astuti RT, 2019).

\section{E. Quantity Evaluation}

Based on research by Nugraha SA et al, 2020 in disaster management logistics owned by BPBD Palembang City there is a shortage in the quantity of operational vehicles for fire trucks and water tankers as well as equipment logistics that can no longer be used such as water pumps, generators, water hoses and faucet nozzles. whose function is to help extinguish fires so that in carrying out their duties they have not run optimally (Nugraha SA, Febryanti D, Kencana N, 2020).

\section{F. Quality Evaluation}

According to Anwar S' 2016 research on service quality levels, service user satisfaction with the services provided by City BPBD officials, in general, can be categorized as sufficient, although there are still complaints from the community, although with relatively small intensity. The quality of services provided to disaster victims has been carried out optimally so that it can be said that the effectiveness of the apparatus at the City Regional Disaster Management Agency is relatively good although in practice there are still complaints from the community. This is due to the lack of understanding of the community in the problems they are facing and here officials are required to be more responsive to complaints, and provide solutions to problems faced by disaster victims. The service quality of the apparatus at the City Regional Disaster Management Agency to the public is measured through spontaneity in dealing with problems, the grace period for solving a problem/work and manners in providing services (Sadat A, 2016).

Service quality consists of various dimensions that are quite complex, so that solving problems with the quality of public services requires a process and ways that are not easy, this requires us to look at problems that arise with various dimensions. In this context, the City Regional Disaster Management Agency is a service media in the field of administration. Thus, it must continue to take corrective steps in all aspects of its activities, in order to improve the performance of its apparatus. The logical consequence for the City Regional Disaster Management Agency as a public service organization is to place disaster victims as the most important factor in carrying out their duties. This is closely related to customer satisfaction with the service quality of the City Regional Disaster Management Agency apparatus, the community's perception is taken from the results of the author's interviews with several disaster victims, as the authors have determined based on available data and documents (Sadat A, 2016).

Based on the results of research by Ambo AA et al in 2016 it can be seen that problems are still found in the implementation of pre-disaster management of the Mount eruption seen from the dimensions of service quality and responsiveness and the Regional Disaster Management Agency of the Regency is mandated to carry out the implementation of pre-disaster management of the Mount eruption and is able to become an organizing agency for the management of preeruption disasters. A mountain that performs well according to what is stated in the organization's vision and mission is seen from the dimensions of productivity, responsibility and accountability (Ambo AA, Sulandari S, Widowati N, 2016).

\section{G. Timeliness and Target Evaluation}

The goal of disaster management is, of course, to minimize the loss of life and property. Many parties are not aware of the importance of managing disasters well. One of the factors is that the disaster does not know when and where it will occur, even though the threat can be predicted. The targets of disaster management are: First, to avoid losses to the community or the state by conducting pre-disaster activities. Second, reducing losses to the community, or the state, related to physical, economic, and environmental aspects. Third, reduce losses suffered by disaster-affected communities. Fourth, to improve the situation so that the community can recover after a disaster, such as repairing damaged development. Fifth, speed up post-disaster recovery and catch up with areas not affected by disasters (Salwa R, Alhadi Z, 2019).

Meanwhile, according to research by Ambo AA et al, in 2016 the Government Agency Performance Accountability Report (LAKIP) should present relevant data and information for decision makers in order to interpret success and failure more broadly and in depth. Performance accountability analysis includes a description of the relationship between the achievement of activity performance with programs and policies in realizing the goals, objectives, mission and vision set out in the strategic plan. This analysis also explains the development of conditions for achieving goals and objectives efficiently and effectively, in accordance with the policies, programs and activities that have been determined. The analysis is carried out using complete and accurate information or data obtained and if possible an evaluation of the policy is also carried out to determine the accuracy and effectiveness of both the policy itself and the system and process for its implementation.

\section{CONCLUSION}

Based on the results of the literature review, it was found 12 articles that discussed human resource input, funding input, infrastructure input, quantity output, quality output, timeliness output and targets on preparedness programs in disaster resilient village activities at the Regional Disaster Management Agency (BPBD).

\section{REFERENCES}

Ambo AA, Sulandari S, Widowati N. 2016. Kinerja Badan Penanggulangan Bencana Daerah dalam Menanggani Pra-Bencana Gunung Slamet di Desa Kutabawa Kecamatan Karangreja Kabupaten Purbalingga Jawa Tengah. Diponegoro Journal of Social and Politik; 5 (2): $1-9$.

Dosen Ilmu Pemerintahan Fakultas Ilmu Sosial dan Ilmu Politik. 2016. Efektifitas Kinerja Badan Penanggulangan Bencana Daerah Pengurangan Resiko Bencana di Kota Baubau. Jurnal Ilmu Pemerintahan: Kajian Ilmu Pemerintahan dan Politik Daerah; 1 (1): 1-20. 
Erlia, D., Kumalawati, R. and Aristin, N. (2017) „Analisis Kesiapsiagaan Masyarakat dan Pemerintah Menghadapi Bencana Banjir di Kecamatan Martapura Barat Kabupaten Banjare, Jurnal Pendidikan Geografi.

Ferdiansyah, Sugiarti C, Atthahara H. 2020. Analisis Penanggulangan Bencana Banjir oleh Badan Penanggulangan Bencana Daerah Kota Bekasi. Jurnal Ilmiah Administrasi Publik dan Pembangunan; 11 (2): 67-78.

Harahap, M. E., Lufti, M. and Muthalib, A. (2015) „Pengaruh Pengetahuan dan Sikap Terhadap Kesiapsiagaan Masyarakat Menghadapi Bencana Banjir di Desa Perkebunan Bukit Lawang, Kecamatan Bahorok, tahun $2011^{\mathrm{ee}}$, Jurnal Ilmiah Keperawatan.

Kristian I, Mulyana Y. 2019. Strategy for Strengthening Instituonal Capacity of Badan Penanggulangan Bencana Daerah (BPBD) in Garut District. Jurnal Pengabdian Kepada Masyarakat; 1 (1): 189-197.

Malahika, M., Rompas, S. and Bawotong, J. (2016) „pengaruh penyuluhan kesiapsiagaan bencana banjir terhadap pengetahuan keluarga di lingkungan i kelurahan pakowa kecamatan wanea kota manado "e, Jurnal Keperawatan UNSRAT.

Margono, Amin MK, Astuti RT. 2020. Kesiapsiagaan Masyarakat di Desa Dukun Kecamatan Dukun Kabupaten Magelang Kawasan Resiko Bencana (KRB) III dalam Penanggulangan Bencana. Jurnal Wiraraja Medika; 9 (2): 35-41.

Najib A, Rahmat HK. 2021. Analisis Pelaksanaan Program Desa Tangguh Bencana di Desa Buluh Cina, Siak Hulu, Kampar, Riau. Jurnal Ilmu Sosial, Politik, dan Humaniora; 5 (1): 14-23.

Nugraha SA, Febriyanti D, Kencana N. 2020. Evaluasi Penanggulangan Bencana Kebakaran di Kota Palembang (Studi Kasus pada Badan Penanggulangan Bencana Daerah Provinsi Sumatra Selatan Tahun 2016-2018). Jurnal Pemerintahan dan Politik; 5 (2): 1-20.

Oktari RS. 2019. Peningkatan Kapasitas Desa Tangguh Bencana. Jurnal Pengabdian Kepada Masyarakat; 4 (2): 189-197.

Razikin dkk (2017) „Strategi Penangulangan Bencana Banjir Berdasarkan Persepsi Masyarakat Di Kecamatan Barabai Kabupaten Hulu Sungai Tengah"e, Jurnal Pendidikan Geografi.

Salwa R, Alhadi Z. 2019. Evaluasi Program Kelurahan Tangguh Bencana di Kota Padang. Jurnal Ilmu Administrasi Publik; 2 (1): 50-59.

Sari Z. 2017. Evaluasi Efektifitas Implementasi Program Penanggulangan Bencana Banjir Kabupaten Aceh Barat. Jurnal Temu Ilmiah Ikatan Penelitian Lingkungan Binaan Indonesia (IPLBI); 1 (1): 1-4.
Sasikome, J., Kumaat, L. and Mulyadi, N. (2015) „1 pengaruh penyuluhan bencana banjir terhadap kesiapsiagaan siswa smp katolik soegiyo pranoto manado menghadapi banjire, Jurnal Keperawatan UNSRAT.

Sulistiyani AT, Yuliana K, Yuliana M. 2017. The Responsiveness and the Ability of "Kampung Tangguh Bencana" in Handling Flood in Yogyakarta City. The Indonesia Journal of Planning and Development; 2 (2): 94-107.

Syarif (2015) „Hubungan Self Efficacy Dengan Kesiapsiagaan Bencana Gempa Bumi Dan Tsunami Pada Siswa Sekolah Menengah Atas Negeri 2 Dan 6 Banda Aceh ${ }^{\text {ee, }}$ Idea Nursing Journal.

Udori A, Miranti. 2019. Upaya Badan Penanggulangan Bencana Daerah (BPBD) dalam Penanggulangan Bencana Banjir. Jurnal Politik dan Pemerintahan Daerah; 1 (2): 85-94.

\section{AUTHORS}

First Author - Husaini, Public Health Study Program, Faculty of Medicine, Lambung Mangkurat University, Indonesia

Second Author - Lenie Marlinae, Public Health Study Program, Faculty of Medicine, Lambung Mangkurat University, Indonesia

Third Author - Laily Khairiyati, Public Health Study Program, Faculty of Medicine, Lambung Mangkurat University, Indonesia

Fourth Author - Agung Waskito, Public Health Study Program, Faculty of Medicine, Lambung Mangkurat University, Indonesia

Fifth Author - Melan Sari, Faculty of Medicine, Lambung Mangkurat University, Indonesia

Sixth Author - Anugrah Nur Rahmat, Public Health Study Program, Faculty of Medicine, Lambung Mangkurat University, Indonesia

Seventh Author - Winda Saukina Syarifatul Jannah, Public Health Study Program, Faculty of Medicine, Lambung Mangkurat University, Indonesia

Eighth Author - Taufik, Public Health Study Program, Faculty of Medicine, Lambung Mangkurat University, Indonesia

Ninth Author - Andre Yusufa Febriandy, Public Health Study Program, Faculty of Medicine, Lambung Mangkurat University, Indonesia

Tenth Author - Ammara Ulfa Azizah, Public Health Study Program, Faculty of Medicine, Lambung Mangkurat University, Indonesia

Correspondence Author - Lenie Marlinae, Public Health Study Program, Faculty of Medicine, Lambung Mangkurat University, Indonesia, Email: bintangara@ulm.ac.id 